\title{
ENHANCE DEMOCRACY: RESILIENCE AND MERITOCRACY
}

\author{
Nobre, S. \\ Post-Doctoral Scientific Researcher at CEPESE /University of Oporto, Portugal \\ sofianobre.psi@gmail.com \\ Rocha, $\mathbf{R}$. \\ Scientific Researcher at CEPESE /University of Oporto, Portugal. \\ Vicente Castro, $\mathbf{F}$. \\ Full Professor (University of Extremadura, Badajoz - Spain) \\ Maldonado Briegas, J.J. \\ Professor (University of Extremadura, Badajoz - Spain)
}

Fecha de Recepción: 21 Febrero 2018

Fecha de Admisión: 10 Abril 2018

\section{SUMMARY}

This paper presents an exploratory study that meant to contribute to the comprehension of the process of formation of Portuguese political elites groups, especially to enlightening if the individual elite status is due to exceptional abilities, assessed by its resilience's categories and professional and academical backgrounds or by "inheritance", due to favorable factors as family and social relationships - that may have induced to a state power type formation that may have led, as one of the major factors, to inequality and mischaracterization of the concept of Democracy itself and to its disbelief, reinforced by the growing corruption and therefore facilitator of populist, dictatorial and xenophobes models that it's urgent to reverse. Concomitantly, it is fundamental to promote resilience-related aspects and merit, to restore society's trust in the system, as WHO (2017) recently explained the importance of trust, measured by the absence of corruption in business and government, to happiness and therefore well-being.

Keywords: Resilience, Democracy, Meritocracy, political, elites.

\section{STATE OF ART}

In the field of elites, mostly to explore, we must go back to 1570, as Monteiro (1997) elucidated that the leadership local role was recognized, by means of monarchic Portuguese legislation, to belong to the "influent people of the lands", in 1603 to the "better of the places" (Orders), in 1618 to the "better of the lands", and in 1709 to the "people of better nobility", according them the "primary positions of the Republic" in the diverse villages of the kingdom, i.e., the honorable positions of sate councils and superior positions of orders. (Foi a própria legislação da monarquia portuguesa a reconhecer o papel de liderança local que cabia às «pessoas principais das terras» (1570), aos 
«melhores dos lugares» (1603, Ordenações), aos «melhores da terra» (1618), às «pessoas da melhor nobreza» (1709), reservando-Ihes os «principais ofícios da República» nas diversas povoações do reino, ou seja, os ofícios honorários das câmaras e os postos superiores das ordenanças (Monteiro, 1997)

Despite the importance of the subject, there is a clear lack of studies in the field of elites' formation and resilience in general. Folke (2016) enlightens, resilience thinking has been used as an organizing principle by communities to challenge the status quo and to design and shape alternative futures. He elucidated that the last 15 years have seen an explosion of resilience research, as a search on resilience, at Google Scholar, presented, February 2016, over 1.25 million hits, about a million of those concerned resilience and the environment. But searching, January 2018, for studies with resilient individuals, only 7 were emerged.

With the actual state of the art of resilience we can understand that resilience is a multidimensional ability to cope with change and adversity and to bounce back, learning from adverse experience and mutable condition, allowing the fundamental process of evolving to well-being, as if adversity had been part of the process and not subject of resentment, frustration or denial, but an opportunity to grow. Resilience can be developed or reinforced, by the training of its categories, which are enlightened by Werner \& Smith (1982), Werner (1992), Connor \& Davidson (2003), Charney (2004), Southwick, Vythilingam \& Charney (2005), Anaut (2005), Jaffee, Caspi, Moffitt, Polo-Tomás \& Taylor (2007), Cicchetti (2010). Lyssenko, Rottmann, \& Bengel (2010), Seery, Holman \& Silver (2010), Veselka, Schermer, Martin \& Vernon (2010), Lopez, A. (2011) e Ungar, M (2011), Chan, Chan \& Kee (2012), Wu et al (2013) and Nobre \& Vicente Castro (2016): good temperament; selfesteem; self-confidence; self-efficacy; self-realization; internal locus of control; initiative; action orientation; success and moderate stress experience; sense of humour; consistency; patience; tenacity; acumen; optimism; intelligence; creativity; flexibility; sense of commitment; pride/brio; autonomy; independence; altruism; empathy; tolerance to negative emotions; faith/spiritual source; capacity to establish strong and affective family and social bonds; capacity to plan realistic goals and recognize opportunities/alternatives; capacity to be alone and adaptation to change.

Hence, we intend to depict how these individuals achieved success, enlightening methods to build, develop or strengthening resilience, announcing future gains in health, as well in economy.

\section{STUDY JUSTIFICATION}

Cicchetti (2010) and Wu et al (2013) alerted that resilience assessment was measured with individuals facing adversity, continuing to be fundamental the study of resilience from a successful perspective, analysing successful individuals, environments, and indicators as productivity and performance, as Waite \& Richardson (2004) pointed the increment of individuals' productivity and performance fundamental to the development of companies, organizations and countries.

Therefore, assessing resilience's categories of successful individuals, as elites, will allow to reveal the exceptional idiosyncratic characteristics and social mechanisms that promote success and life satisfaction - How they achieve success and recover homeostasis and life satisfaction, after adversity period or stressful situations, and rise up, progress, again and again, as long as they assure, as explained by (Nobre \& Castro, 2016a), the necessary period of time between adverse events and conditions to recover not only homeostasis but also real pleasure for life.

Thus, this study will allow progress in a new perspective of conception of interventional models, studying successful individuals, as Pfau \& Russo (2015) corroborated the recommendation of Ciccheti and Wu et al, underlining that an enhanced focus on resilient subjects enable successful treatment of stress-related disorders. Future gains are foreseeable in economy and health, through 
resilience's categories development, by incrementing productivity and performance and guarantying with the reinforcement of resilience, better health, reflecting a reduction of costs, by decrease in medication consumption, consequently unburdening national health system services' (WHO, 2013).

Understanding resilience's categories will also benefit health care and palliatives providers, emergency workers, instructors and potential entrepreneurs by strengthening their resilience.

Understanding elites' formation, its liaisons and mobility, and elites' resilience promoting success, life satisfaction and well-being, in accordance with UN's 2030 Agenda, will certain contribute to bringing to the light one of the major questions concerning human development: to engage society in a healthier, wealthier and more peaceful way of life, in a time when transparent, fairer and inclusive politics are demanded by citizens all over the world.

\section{OBJECTIVES}

This study has the main objective of making clearer the formation of elites, by means of their characterization, analyses of sociodemographic data, and their mobility in terms of positions. We also aim at understand if the individuals' elite status is due to their academic and professional merit and to exceptional characteristics identifiable with resilience-related categories, or due to 'inheritance', i.e. favourable factors such as family and social relationships.

This study aims to correspond to 2030 ONU objectives, particularly contributing to the development of equality, eradicating the opportunities of corruption, and reinforcing the knowledge of resilience, determinant to an healthy society, restoring confidence in the Democratic government system, by bringing to the light the processes by which the elites' groups are formed, hoping resulting dissuasive to inadequate favour relationships and corruption, and allowing that transparency and meritocracy emerges reinforced and demanded by citizens. We hope, this study may also to stimulate Portuguese citizens about the quality of Portuguese elites, that we wish all actively attentive, committed and involved to the evolution and transformation of the social paradigm to one more supportive, fairer and inclusive.

With this study we intend, as well, to create an analysis model for Portugal, supported by Grounded Theory Methodology (Strauss \& Corbin, 98), allowing to implement fair politics and to understand and supervise elite's groups' mobility, as it is intended to allow, in the future, to extend it to global reality, since it is supposed to be generalizable.

By inherence, this study aims to reinforce scientific international partnerships, to disseminate knowledge globally and to generate more information and interest for the subject.

\section{MAIN QUESTIONS}

1. Do elites' individuals rely on their own merits, such as adequate education and experience?

2. Is their success due to identifiable favourable relationships?

3. Do they become wealthier by means of unclear/illegal ways?

4. Does political positions imply prior relevant positions in public and/or private institutions?

5. Is success dependent of resilience's categories?

\section{METHODOLOGY}

Concerning data collection, we intend to assess socio-historic-psychological data on elites' individuals, preferentially by direct interviews with inherent informed Consent, and when not possible, by resorting to public domain sources, and then proceeding with content analysis (Bardin, 95).

This exploratory study allows quantitative approach for data analyse by SPSS (Statistical Package for the Social Sciences), we will verify the following hypotheses (together with others that may emerge as relevant): 
H1: Elite positions are correlated with specific combinations of gender, age, place of residence, professional career, political affiliations, education, honourable titles, awards and public achievements, personal wealth and family and personal relationships

H2: Professional career is correlated with specific combinations of gender, age, place of residence, political affiliations, education, honourable titles, awards and public achievements, personal wealth and family and personal relationships

H3: Personal wealth increments proportionally with wage and age

$\mathrm{H} 4$ : Higher resilience is correlated with specific combinations of gender, age, place of residence, professional career, political affiliations, education, honourable titles, awards and public achievements, personal wealth and family and personal relationships

H5: Success (measured by professional career, personal wealth, honourable titles, awards and public achievements) is correlated with specific combinations of resilience's categories and success of family and personal relationships.

\section{SAMPLE}

We will consider 144 individuals, which is a representative sample (with $95 \%$ of reliability and 5\% error) of parliament members from legislative elections of 2015.

Parliament with 230 Members, observing balance between the number of members of the 2 major Portuguese parties: PPD/PSD: 89; PS: 86; BE: 19; CDS-PP: 18; PCP: 15; PEV: 2 and PAN: 1 (in http://www.parlamento.pt)

\section{ASSESSMENT PROTOCOL}

1- Semi-structured interview created to collect sociodemographic data and to assess resilience's categories and well-being, based on the contribution of Werner \& Smith (1982), Werner (1992), Connor \& Davidson (2003), Charney (2004), Southwick, Vythilingam \& Charney (2005), Anaut (2005), Jaffee, Caspi, Moffitt, Polo-Tomás \& Taylor (2007), Cicchetti (2010). Lyssenko, Rottmann, \& Bengel (2010), Seery, Holman \& Silver (2010), Veselka, Schermer, Martin \& Vernon (2010), Lopez, A. (2011) e Ungar, M (2011), Chan, Chan \& Kee (2012), Wu et al (2013) and Nobre \& Vicente Castro (2016), including: name; date and place of birth and decease; gender; place of residence; education; political party; political positions; institutional positions; work positions; professional career; wage; personal wealth; honourable titles, awards and public achievements; marital status; family members and personal relationships with social relevance.

2- Resilience assessment (CDRISC, Connor \& Davison, 2003, validated for Portuguese population by Faria \& Ribeiro, 2008).

\section{FINAL CONSIDERATIONS}

With this study, we aim to contribute to disseminate knowledge of elites and to promote wellbeing, by acknowledging resilience's categories, determinant to a healthy, wealthy and peaceful society. By making better known the processes by which elite groups are formed, we hope to help dissuading inequality and corruption phenomena, improving people's confidence in Democracy, allowing that transparency and meritocracy emerge reinforced. We aim, it will also contribute for a more attentive and demanding citizenship, committed and involved with the evolution and transformation of the social paradigm to a more equal and 'all-inclusive' one.

\section{REFERENCES}

Anaut, M. (2005). A Resiliência - Ultrapassar os traumatismos (Emanuel Pestana Trad.). Lisboa: Climepsi. 
Bardin, L. (1995). Análise de Conteúdo (Luís Antero Reto e Augusto Pinheiro Trad.). Lisboa : Edições 70. (Original 1977)

Chan, A.O., Chan, Y.H. \& Kee, J.P. (2012). Improving resistance and resiliency through crisis intervention training. Int J Emerg Ment Health 14(2):77-86.

Cicchetti, D. (2010). Resilience under conditions of extreme stress: a multilevel perspective. World Psychiatry 9(3): 145-154.

Connor, K.M. \& Davidson, J.R. (2003). Development of a new resilience scale: the Connor-Davidson Resilience Scale (CD-RISC). Depression and Anxiety 18:76-82.

Folke, C. (2016). Resilience. Ecology and Society, 21(4):44. (republication of Folke, C. 2016. "Resilience" of the Oxford Research Encyclopedia of Environmental Science)

Lyssenko, L., Rottmann, N. \& Bengel, J. (2010). Research on psychological resilience. Relevance for prevention and health promotion. Bundesgesundheitsblatt Gesundheitsforschung Gesundheitsschutz 53(10):1067-72.

Lopez, A. (2011). Posttraumatic stress disorder and occupational performance: building resilience and fostering occupational adaptation. Work.38 (1):33-8.

Monteiro, N. (1997). Elites locais e mobilidade social em Portugal nos finais do Antigo Regime. Análise Social (2. $\left.{ }^{\circ}\right)$, vol. xxxii (141): 335-368

Nobre Frank, S. (2012). A Ginástica Pathosplástica da Perturbação Anti-Social da Personalidade. Int. J. Dev. and Educ. Psychology, Vol.4:179-188.

Nobre, Reis, Castro \& Esteves (2013). Felicidade, Amor e Arte (Happiness, Love and Art. Exploratory Study about the Art of Well Aging). Int. J. Dev. and Educ. Psychology, Vol.2:421-430

Nobre, Castro \& Esteves (2013). CatÁrtese: Desenho de uma técnica terapêutica (CathÁrtesis: drawing a therapeutic technique. Int. J. Dev. and Educ. Psychology, Vol.2:561-568.

Nobre, Esteves \& Castro (2013). Resilience: new paradigm - from love to death. Atas of International Congress History of Madness, Psychiatry and Mental Health, University of Coimbra.

Nobre, Castro \& Esteves (2014). Produtividade: Critica(I) Resiliência. Modelo de Intervenção Terapêutica para Desenvolvimento da Produtividade. Int. J. Dev. and Educ. Psychology, Vol 5: 251-256.

Nobre \& Castro (2016a). 0 Lado Negro da Resiliência. Int. J. Dev. and Educ. Psychology, Vol. 2:165172.

Nobre \& Castro (2016b) Neurobiologia da Resiliência: em busca de lesão por um futuro consciente. Int. J. Dev. and Educ. Psychology, 1, Vol. 2:157-164.

Nobre, Maldonado Briegas \& Castro (2017). Resilience's Psychophisiology: Preventing Breakdown. Int. J. Dev. and Educ. Psychology, $N^{\circ} 1$, Vol 1:77-84.

Nobre, Maldonado-Briegas, Luchese \& Castro (2017). A Psicobiologia do Autismo - Reflexão sobre promessas terapêuticas. Confinia Cephalalgica et Neurologica vol.27, № $3: 117-126$.

Seery, M.D., Holman, E.A. \& Silver, R.C. (2010). Whatever does not kill us: cumulative lifetime adversity, vulnerability, and resilience. Journal of Personality and Social Psychology. 99(6):1025-41.

Pfau \& Russo (2015). Peripheral and central mechanisms of stress resilience. Neurobiology of Stress, 1: 66-79.

Reis, Nobre \& Castro (2016). Álcool na escola - uma reflexão sobre prevenção e consequência. Int. J. Dev. and Educ. Psychology, 1, Vol2: 207-214.

Southwick, S.M., Vythilingam, M. \& Charney, D.S. (2005). The psychobiology of depression and resilience to stress: implications for prevention and treatment. Annu Rev Clin Psychol.1:255-91.

Strauss, A. \& Corbin, J. (1998) Basics of Qualitative Research - Techniques and Procedures for 
Developing Grounded Theory. London : Sage Publications.

Ungar, M. (2011). The social ecology of resilience: addressing contextual and cultural ambiguity of a nascent construct. American Journal of Orthopsychiatry 81(1):1-17.

Veselka, L., Schermer, J.A., Martin, R.A. \& Vernon, P.A. (2010). Laughter and resiliency: a behavioral genetic study of humor styles and mental toughness. Twin Research and Human Genetics 13(5):442-9.

Waite, P.J. \& Richardson, G.E. (2004). Determining the efficacy of resiliency training in the work site. J Allied Health 33(3):178-83.

Werner, E. E. \& Smith, R. S. (1982). Vulnerable but invincible: A longitudinal study of resilient children and youth. New York: McGraw-Hill.

Werner, E.E. (1992) The children of Kauai: resiliency and recovery in adolescence and adulthood. Journal of Adolescence Health 13:262-268.

WHO (2013). Comprehensive mental health action plan 2013-2020. Sixty-sixth world health assembly. Document A66/10 Rev.1 in http://www.who.int/mental_health /mhgap/consultation_global_mh_action_plan_2013_2020/en/index.html)

WHO (2017). WORLD HAPPINESS REPORT. http://worldhappiness.report/wp-content/ uploads/sites/2/2017/03/HR17.pdf

Wu, G., Feder, A., Cohen, H., Kim, J.J., Calderon, S, Charney, D.S. \& Mathé, A.A. (2013). Understanding resilience. Frontiers Behavioral Neuroscience 7:10. 